\title{
THYROID FUNCTION IN DOGS WITH VISCERAL LEISHMANIASIS
}

\section{FUNÇÃO TIREOIDIANA DE CÃES COM LEISHMANIOSE VISCERAL}

\author{
Mauro Jose Lahm Cardoso ${ }^{1 *}$ \\ Maira Melussi² \\ Rafael Fagnani ${ }^{3}$ \\ Luciane Holsback ${ }^{4}$ \\ Thais Helena Patelli ${ }^{4}$ \\ Eunice $\mathrm{Oba}^{5}$ \\ ${ }^{1}$ Universidade Estadual de Londrina,Londrina, PR, Brasil. \\ ${ }^{2}$ Médica Veterinária Autônoma, Londrina, PR, Brasil. \\ 3Universidade Estadual do Norte do Paraná, Londrina, PR, Brasil. \\ ${ }^{4}$ Universidade Estadual do Norte do Paraná, Bandeirantes, PR, Brasil. \\ ${ }^{5}$ Faculdade de Medicina Veterinária e Zootecnia da Universidade Estadual Paulista, Botucatu, SP, Brasil. \\ *Autor para correspondência - maurolahm@gmail.com
}

\begin{abstract}
Several non-thyroid factors such as age, breed, concomitant diseases and use of certain drugs might influence the diagnosis of hypothyroidism in dogs. Changes in the concentrations of thyroid hormones due to non-thyroid illnesses are named euthyroid sick syndrome. The aim of this study was to evaluate the influence of visceral leishmaniasis on thyroid function in dogs without clinical signs of hypothyroidism, with or without azotemia. Positive animals for leishmaniasis were divided into six groups (absence or presence of hypoalbuminemia, normal or increased creatinine, normal or increased urea). The effect on these groups was evaluated on the thyroid-stimulating hormone (TSH), total thyroxine (TT4) and free thyroxine (FT4) concentrations. Dogs that were positive for leishmaniasis, by ELISA test, presented thyroid-stimulating hormone serum concentrations greater than seronegative animals, while total thyroxine and free thyroxine in dogs with leishmanisis were lower $(\mathrm{P} \leq 0.01)$ when compared to healthy dogs. However, the results were within the values for euthyroid animals. In seropositive dogs for leishmaniasis, TT4 showed statistically significant difference $(\mathrm{P} \leq 0.04)$ in the group with hypoalbuminemia compared to the group with normoalbuminemia, respectively, 1,01ug/ $\mathrm{dL}$ and $1.4 \mathrm{~g} / \mathrm{dL}$. Based on this study, we could conclude that positive dogs for visceral leishmaniasis have not presented euthyroid sick syndrome, although when compared to healthy dogs, FT4 and TT4 were reduced and TSH increased.
\end{abstract}

Keywords: euthyroid; hypothyroidism; leishmania; sick syndrome; thyroxine.

\section{Resumo}

Vários fatores extratireoidianos como idade, raça, doenças concomitantes e fármacos podem influenciar na função e no diagnóstico do hipotireoidismo em cães. As alterações nas concentrações dos hormônios tireoidianos decorrentes de doenças não tireoidianas é denominada de síndrome do eutireoideo doente. O objetivo deste estudo foi avaliar a influência da leishmaniose visceral na função da tireoide em cães sem sinais de hipotireoidismo, com ou sem azotemia. Os animais positivos para leishmaniose foram divididos em seis grupos (albumina nornal ou diminuída, creatinina normal ou elevada, uréia normal ou elevada) e foi avaliado o efeito nesses grupos das concentrações séricas do hormônio estimulante da tireoide (TSH), tiroxina total (TT4) e da tiroxina livre (FT4). Os cães positivos para leishmaniose, pelo teste de ELISA, apresentaram concentrações séricas de TSH mais elevadas do que os animais soronegativos, enquanto que as concentrações de TT4 e FT4 em cães com leishmaniose foram menores $(P<0,01)$ quando comparadas com as dos cães saudáveis. No entanto, 
os resultados estavam no intervalo dos valores para os animais eutireoideos. Nos cães seropositivos para leishmaniose, a TT4 apresentou diferença estatística significativa $(\mathrm{P}<0,04)$ no grupo com hipoalbuminemia em relação ao grupo com normoalbuminemia, respectivamente, 1,01ug/dL e 1,4ug/ dL. Concluiu-se que os cães positivos para a leishmaniose visceral não desenvolveram síndrome do doente eutireóide, embora as concentrações de TT4 e a FT4 estivessem reduzida e de TSH elevada em relação aos cães sem leishmaniose.

Palavras-chave: eutiroidismo; hipotireoidismo; leishmania; síndrome do doente eutireoideo; tiroxina.

Enviado em: 07 julho 2014

Aceito em: 07 fevereiro 2016

\section{Introduction}

Alterations in thyroid hormone concentrations in response to non-thyroid illnesses (NTIs), often termed as the euthyroid sick syndrome (ESS), are well recognized in both animals and human. Several nonthyroid factors such as age, breed, concomitant diseases and use of certain drugs might influence the diagnosis of hypothyroidism in dogs. ${ }^{(1-5)}$ Also, the stress induced by non-thyroid illnesses might cause an increase of circulating glucocorticoids (prednisone, dexamethasone) and alter the thyroid function. (6) In severe illnesses, a reduction in TT3 and TT4 might happen. In these cases, the free portion of the hormone remain within normal levels. ${ }^{(7-9)}$ Disorders that are frequently associated with NITs in dogs include neoplasia, renal disease with increased blood urea nitrogen (BUN) and creatinine, hepatic disease, cardiac failure, neurologic disease, inflammatory disorders, and diabetic ketoacidosis. ${ }^{(4,10)}$

However, in dogs, a decrease only in TT3 concentrations is not common, but described in babesiosis. Most of the time, there is a reduction both in TT3 and TT4 and, in a few cases, only in TT4. Nonetheless, free thyroxin (FT4) is less affected by NTIs, with only mild decreases in severe systemic diseases. (3) Among the diseases with potential to provoke a decrease in thyroid hormones, there are infectious diseases such as parvovirosis, babesiosis, and leishmaniosis.

Canine visceral leishmaniasis is a severe systemic disease, which may cause kidney and liver disorders, cardiac injuries as well as to other organs. Parvovirosis, babesiosis, leishmaniosis, and other severe systemic diseases can cause euthyroid sick syndrome. ${ }^{(6,11-14)}$ These diseases increase the production of pro-inflammatory cytokines, such as TNFa and IL-6, to cause inhibition of the hypothalamushypophysis-thyroid axis, resulting in a decrease in the production, secretion and circulation of thyroid hormones (T3 and T4). ${ }^{(15-17)}$ Cytokines, such as interleukin beta 1 (IL-ß1) and 6 (IL-6) and tumor necrosis factor (TNF) have inhibitory effect on TSH secretion when administered to animals. ${ }^{(18)}$ This effect has been attributed to both direct actions and indirect pituitary hypothalamus. IL- $ß 1$ and IL-6 are potent inflammatory mediators whose production is increased in acute systemic diseases, and they are associated with activation of the adrenal in these situations. It is possible that these cytokines participate in the changes of the thyroid axis observed in acute diseases, not thyroid, including by stimulating the pituitary deiodinase activity. ${ }^{(19,20)}$ However, the effect of interleukins on thyroid function in humans and animals is not very clear.

The diagnosis of leishmaniasis is based on clinical signs and clinic pathological abnormalities. Results of complete blood count (CBC), biochemical profile and urinalysis can be both wide and nonspecific. The definitive diagnosis can be established by the detection of specific serum antibodies (IgG) using preferably quantitative serological techniques, such as the immunofluorescence antibody test (IFAT) and enzyme linked immunosorbent assay (ELISA), immunochromatography and PCR. ${ }^{(21)}$

The function of the thyroid gland is typically initially assessed by measuring baseline serum thyroid hormone concentrations. Baseline tests to assess thyroid gland function include measurement of the TT4, FT4, reverse triiodothyronine (rT3), total (TT3) and free (FT3) triiodotirnonine, and antibody tests for lymphocytic thyroiditis. ${ }^{(6,10)}$

Thus, the aim of this study was to evaluate the influence of visceral leishmaniasis on the thyroid function of dogs without signs of hypothyroidism, with or without azotemia. 


\section{Materials and Methods}

One hundred thirty-eight adult, mixed breed dogs were enrolled in the study. Eighty-five were female (forty-nine sexually intact) and fifty-three were male (thirty-five sexually intact). All animals came from the endemic area of visceral leishmaniasis, Campo Grande, Mato Grosso do Sul, Brazil, selected from March to December, 2012. Most sick animals had signs compatible with visceral leishmaniosis (emaciation, lymphadenopathy, cutaneous and ocular abnormalities, and splenomegaly were most common). Animals with signs compatible with hypothyroidism - such as lethargy, obesity and dyslipidemia - history of hormone replacement, and usage of drugs that interfere with the thyroid function were excluded from the study.

The blood samples for serum biochemical analyses and ELISA were collected in test tubes and were kept at room temperature for 30 minutes to coagulate, and then were centrifuged. Sera were prepared and immediately analyzed, or stored at $4{ }^{\circ} \mathrm{C}$ for analysis in a period of up to $24 \mathrm{~h}$ after collection, using a Semi-Automatic Biochemical Analyzer (TP-Analyzer Plus, Bio Técnica, Varginha-MG, Brasil) and appropriate commercial kits (Bio Técnica, Varginha-MG, Brasil) for albumin, urea, and creatinine. Normal serum values for the study were considered as creatinine between $0.5-1.5 \mathrm{mg} / \mathrm{dL}$; urea between 21.4-59.9 mg/dL and albumin between 2.6-3.3 g/dL.

Leishmaniasis diagnostic for the 138 samples was established using ELISA (Leishmania chagasi $\mathrm{kit}^{\circledR}$, Biomanguinhos, Brasil) technique. A total of 95 positive and 43 negative dogs for Leishmania sp were verified.

Positive animals for leishmaniasis were divided in six groups regarding: absence of hypoalbuminemia (Group 1-G1), presence of hypoalbuminemia (Group 2-G2), normal creatinine (Group 3-G3), increased creatinine (Group 4-G4), normal urea (Group 5-G5) and increased urea (Group 6-G6).

Total T4 was measured using a commercial solid-phase radioimmunoassay kit (Clinical Assays Gammacoat M Total T4 RIA Kit; DiaSorin Inc., Stillwater, MN, USA) that has already been validated for canine serum. ${ }^{(22)}$ Free T4 was measured by a commercial available kit (Free T4 by equilibrium dialysis; Nichols Institute Diagnostics, San Juan Capistrano, CA, USA) that has been validated in that laboratory for canine serum. ${ }^{(22)}$ Canine TSH was measured using a commercial available immunoradiometric assay (Coat-A-Count canine TSH IRMA; Diagnostic Products Corp., Los Angeles, CA, USA) that has been validated in that laboratory for canine serum. ${ }^{(22)}$ Normal values for thyroid-stimulating hormone (TSH) were $0.18-1 \mathrm{ng} / \mathrm{dL}$, for TT4 1.5-4 ug/dL and for FT4 1.0-4.0 $\mathrm{ng} / \mathrm{dL} \cdot{ }^{(6,10,22)}$

The experimental design was entirely randomized, evaluating the effect of Leishmaniasis on the variables TSH, TT4 and FT4. All variables were previously submitted to Kolmorogov-Smirnov and Lilliefors to check normality and homocedasticity, and did not follow normal distribuition. Thus, the comparison between seropositive and seronegative dogs was evaluated by Mann-Whitney test with $\mathrm{P} \leq 0.05$. All analyses were performed using Statica 7.0 program for Windows ${ }^{\circledR} .{ }^{(23)}$

\section{Results}

From the 138 evaluated dogs, 95 were seropositive for leishmaniasis and 43 were seronegative. Seropositive dogs presented serum TSH concentration greater than seronegative animals, while TT4 and FT4 in dogs with leishmaniasis were lower when compared to healthy dogs (Table 1), without significant difference between groups. However, both groups presented values within reference range for the species, thus, all of them are considered euthyroid animals.

The values of TSH, TT4 and FT4 of the groups regarding the values of albumin (G1 and G2), creatinine (G3 and G4) and urea (G5 and G6) are shown in Table 2.

In dogs that were seropositive for leishmaniasis, no significant differences were observed among animals with increased urea and creatinine, and those with values within reference levels (Table 2). In seropositive dogs, TT4 mean in group G5 was lower $(\mathrm{P} \leq 0.05)$ when compared to the mean in group G6. The remaining groups have not presented statistic differences between each other (Table 2). 
Table 1: Results of serum TSH, TT4 and FT4 concentrations in both groups of seropositive dogs (95 dogs) and seronegative (43 dogs) dogs for leishmaniasis (Leishmania infantum chagasi)

\begin{tabular}{llccc}
\hline & & Seronegative dogs & Seropositive dogs & Reference values \\
\hline TSH $(\mathrm{ng} / \mathrm{mL})$ & Mean \pm SD $(\mathrm{n})$ & $0.43 \mathrm{a} \pm 0.23(43)$ & $0.63 \mathrm{~b} \pm 0.32(95)$ & $(0.18-1)$ \\
& Range & $0.13-0.94$ & $0.14-1.20$ & \\
& $\mathrm{P}$ & \multicolumn{2}{c}{$\leq 0.01$} & \\
\hline TT4 $(\mu \mathrm{g} / \mathrm{dL})$ & Mean $\pm \mathrm{SD}(\mathrm{n})$ & $2.31 \mathrm{~b} \pm 0.81(43)$ & $1.28 \mathrm{a} \pm 0.85(95)$ & $(1.5-4.0)$ \\
& Range & $0.67-3.96$ & $0.29-4.37$ & \\
& $\mathrm{P}$ & \multicolumn{4}{c}{$\leq 0.01$} & $(1.0-4.0)$ \\
\hline FT4 $(\mathrm{ng} / \mathrm{dL})$ & Mean $\pm \mathrm{SD}(\mathrm{n})$ & $1.84 \mathrm{~b} \pm 0.51(43)$ & $1.49 \mathrm{a} \pm 1.81(95)$ & \\
& Range & $1.01-2.46$ & $0.39-1.50$ & \\
& $\mathrm{P}$ & \multicolumn{4}{c}{$\leq 0.01$} & & \\
\hline
\end{tabular}

Means followed by different letters present significance ( $\mathrm{P} \leq 0.05)$ according to Mann-Whitney test. SD-Standard deviation, (n) - number of animals, TSH-thyroid-stimulation hormone, TT4-total thyroxine, FT4-free thyroxine.

Table 2: Means of serum TSH, TT4 and FT4 concentrations in the six groups of 95 dogs with leishmaniasis (Leishmania infantum chagasi)

\begin{tabular}{llcccccc}
\hline & Group & G1 & G2 & G3 & G4 & G5 & G6 \\
\hline TSH ng/mL & Mean (n) & $0.62(53)$ & $0.62(39)$ & $0.62(53)$ & $0.63(42)$ & $0.61(53)$ & $0.65(42)$ \\
& SD & 0.31 & 0.34 & 0.31 & 0.34 & 0.31 & 0.35 \\
& Range & $0.18-1.2$ & $0.14-1.2$ & $0.18-1.2$ & $0.14-1.2$ & $0.17-1.2$ & $0.14-1.2$ \\
& P & \multicolumn{2}{c}{0.97} & \multicolumn{2}{c}{0.84} & \multicolumn{2}{c}{0.57} \\
\hline TT4 (ug/dL) & Mean (n) & $1.43(53)$ & $1.11(49)$ & $1.37(53)$ & $1.15(42)$ & $1.4 a(63)$ & $1.01 \mathrm{~b}(33)$ \\
& SD & 0.96 & 0.66 & 0.97 & 0.66 & 0.93 & 0.6 \\
& Range & $0.29-4.37$ & $0.43-2.8$ & $0.29-4.4$ & $0.43-2.8$ & $0.29-4.4$ & $0.34-2.8$ \\
& P & \multicolumn{2}{c}{0.07} & \multicolumn{2}{c}{0.21} & \multicolumn{2}{c}{0.04} \\
\hline FT4 (ng/dL) & Mean (n) & $1.39(53)$ & $1.92(49)$ & $1.38(53)$ & $1.63(42)$ & $1.39(63)$ & $1.67(33)$ \\
& SD & 1.52 & 2.77 & 1.52 & 2.13 & 1.40 & 2.41 \\
& Range & $0.39-1.5$ & $0.89-1.5$ & $0.39-1.2$ & $0.89-1.5$ & $0.39-1.2$ & $0.89-1.5$ \\
& P & \multicolumn{2}{c}{0.24} & \multicolumn{2}{c}{0.50} & \multicolumn{2}{c}{0.48} \\
\hline
\end{tabular}

Means followed by different letters present significance $(P \leq 0.05)$ according to Mann-Whitney test. Significant difference between G5 and G6 ( $<<0.05)$. SD-Standard deviation, (n)-number of animals, TSH-thyroid-stimulation hormone, TT4-total thyroxine, FT4-free thyroxine, G1-absence of hypoalbuminemia, G2-presence of hypoalbuminemia, G3-normal creatinine, G4-increased creatinine, G5-normal urea, G6-increased urea.

\section{Discussion}

The decrease in FT4 concentrations poses a positive feedback on the hypophysis, stimulating the production and secretion of TSH, which could justify the increase in TSH serum concentrations. However, probably these levels of cytokine are not enough to cause ESS such as the one described in animals with babesiosis and parvovirosis. ${ }^{(6,11-13)}$ It seems probable that the level of parasitism for leishmaniasis and the severity of the disease can also influence the concentrations of thyroid hormones as observed in canine babesiosis. ${ }^{(19)}$

It seems likely that the decrease in TT4 and FT4, as well as the elevation in TSH concentrations in infected dogs resulted from production of pro-inflammatory cytokines (leading to suppression of pituitary TSH secretion) and increased deiodinase activity, an enzyme, which causes transformation of thyroxin into triiodothyronine suppressing TRH production, in the hypothalamus. ${ }^{(15,24)}$ 
Leishmaniasis causes several systemic alterations, including liver and kidney disorders. These alterations are well-described as causes of euthyroid sick syndrome (ESS), since hypoalbuminemia and azotemia/uremia change the function of the hypothalamus-hypophysis-thyroid axis. ${ }^{(3,26)}$ In $\operatorname{dogs}$ that are seropositive for leishmaniasis, no significant differences were observed among animals with increased urea and creatinine, and those with values within normal levels (Table 2). The decrease in free and total thyroxin concentrations was described in babesiosis,${ }^{(12,13)}$ without significant differences between azotemic and non-azotemic animals. In studies with babesiosis, TSH serum concentrations were not altered. ${ }^{(12)}$ Unlike the previous study where euthyroid sick syndrome was associated with elevated BUN and serum creatinine, in this study, only statistical difference in the group with urea elevation was observed. The difference is probably due to the characteristics of the disease because leishmaniasis is a chronic disease and babesiosis is the acute nature of the disease. It is known that, in hypothyroidism, a decreased cardiac output is associated with a decrease in renal blood flow and glomerular filtration rate. In hypothyroid humans, glomerular filtration rate may be reduced up to $40 \%$ and is associated with an increase in serum creatinine concentration. (27)

Hypoalbuminemia might occur in liver, kidney and enteric diseases with loss of proteins and chronic inflammations. Probably, hypoalbuminemia in these animals with leishmaniasis is due to liver and kidney injuries, and also due to chronic inflammation. In seropositive dogs for leishmaniasis, TT4 mean in $\mathrm{G} 5$ was lower $(P \leq 0.05)$ when compared to the mean in $\mathrm{G6}$. The remaining groups did not present statistic differences among each other (Table 2). Albumin, together with other proteins, is an important thyroxin transporter. ${ }^{(4)}$ The decrease in albumin, and probably in other proteins such as transthyretin, ${ }^{(28)}$ has probably influenced the decrease in TT4 concentrations.

The decrease in albumin in seropositive dogs could have also been due to kidney diseases; however, no urinalysis was performed to investigate the presence of proteinuria and not urine protein to creatinine (UP/C) ratio. Besides, in a few cases, hypoalbuminemia could be caused by intestinal protein loss or malnutrition, since these dogs were from shelters.

Despite the decrease in TT4 and FT4 concentrations and the increase in TSH, the animals in this study would not have been confused with hypothyroid animals, since the concentrations of thyroid hormones were within the range of euthyroidism. The mild decrease in TT4 concentrations, despite hypoalbuminemia, indicates that other transporting proteins were not decreased. However, this was not investigated in this study.

The presence of chronic dermatologic alterations and even neuropathies are differential diagnosis both for hypothyroidism and leishmaniasis. Thus, thyroid function tests can be requested and can be compatible with hypothyroidism. Nonetheless, in areas with high prevalence of leishmaniosis, the authors recommend serology and PCR for this disease, since it might cause decrease in FT4 and TT4 and increase in TSH, findings which are compatible with hypothyroidism.

Also, the increase in the production of anti-thyroglobulin (TG) antibodies in several systemic diseases, ${ }^{(10,29)}$ an important transport protein for thyroid hormones, which might intensify the decrease in TT4, has already been described. However, in these cases, normal or increased FT4 is expected. Production and/or circulation of anti-TG antibodies were not analyzed in this study.

Based on this study, it is possible to state that animals that were positive for visceral leishmaniasis did not develop NITs. To our knowledge this is the first study of the influence of leishmaniasis in thyroid function. There is a study evaluating thyroid function in animals receiving treatment for leihsmaniose.

(14) However, further studies are necessary in order to evaluate thyroid functions in animals with severe signs of leishmaniasis. Moreover, the presence or absence of azotemia has not interfered in the thyroid function and only a reduction in albumin decreases TT4 concentrations.

\section{Conclusions}

The decrease in thyroid hormones in dogs with leishmaniosis was not enough to produce ESS. Based on this study, we could conclude that seropositive dogs for visceral leishmaniasis have not presented euthyroid sick syndrome, when compared to seronegative dogs . 


\section{Acknowledgments}

The authors would like to thank Fundação Araucária and Conselho Nacional de Pesquisa (CNPq) for the financial support for this research.

\section{References}

1-Ferguson DC. The effect of nonthyroidal factors on thyroid function tests in dogs. Comp Cont Educ Prac Vet. 1997, 10:1365-1377.

2-Scott MJC, Nelson RW, Bruner JM, Williams DA. Comparison of serum concentrations of thyroid-stimulating hormone in healthy dogs, hypothyroid dogs, and euthyroid dogs with concurrent disease. J Am Vet Med Assoc. 1998 February 212(3): 387-391.

3-Kantrowitz LB, Peterson ME, Mellian C, Nichols R. Serum total thyroxine, total triiodothyronine, free thyroxine, and thyrotropin concentrations in dogs with nonthyroidal disease. JAm VetMedAssoc. 2001 Septmeber 219(6):765-769. Available from: http://avmajournals.avma.org/doi/abs/10.2460/javma.2001.219.765

4-Cardoso MJL, Zacarias-Júnior A, Oliveira RR, Maciéski ES. Papel dos fármacos na função tireoidiana em cães. Clínica Veterinária. 2007 maio/junho 12(68):68-76.

5-Fialkovicová M, Mardzinová S, Benková M, Mojzisova J, Gaálova M, Sesztakova E. Seasonal influence on the thyroid gland in healthy dogs of various breeds in different weights. Acta Vet Brno. 2012 81(2):183-188. Available from: http://actavet.vfu.cz/81/2/0183/ doi:10.2754/avb201281020183

6-Mooney CT, Shiell RE, Dixon RM. Thyroid hormone abnormalities and outcome in dogs with non-thyroidal illness. J Small Anim Prac. 2008 January 49(1):11-16. Available from: http://onlinelibrary.wiley.com/ doi/10.1111/j.1748-5827.2007.00418.x/full

7-Yilzdas D, Mungan ON, Yapicioglu H, Topaloglu H, Topaloglu AK, Sertdemir Y, Yuksen B. Thyroid hormone levels and their relationship to survival in children with bacterial sepsis and septic shock. J Pediat Endocrinol Metabol. 2004 October 17(10):1435-1442. Available from: http://www.degruyter.com/view/j/ jpem.2004.17.10/jpem.2004.17.10.1435/jpem.2004.17.10.1435.x.

8-Dagan O, Vidne B, Josefsber Z, PhilipM, Strich D, Erez E. Relationship between changes in thyroid hormone level and severity of the postoperative course in neonates undergoing openheart surgery. Paediatric Anaesth. 2006 March 16(5):538-542. Available from: http://onlinelibrary.wiley.com/doi/10.1111/j.14609592.2005.01808.x/pdf

9-Golombek SG. Nonthyroidal illness syndrome and euthyroid sick syndrome in intensive care patients. Semin Perinatol. 2008 December 32(6):413-418. Available from: http://www.sciencedirect.com/science/article/pii/ S0146000508001171. doi:10.1053/j.semperi.2008.09.010.

10-Scott-Moncrieff, J.C. Hypothyroidism. In: Feldman, E.C., Nelson, R.W., Reusch, C.E., Scott-Moncrieff, J.C. Behrend, E.N. Canine \& Feline Endocrinology. $4^{\circ}$ Ed. Fhiladelphia: Elsevier, 2015. E-book. English.

11-Elliot DA, King LG, Zerbe C.A 1995: Thyroid hormone concentrations in critically ill intensive care patients. J Vet Emerg Crit Care, 1995 July 5(7):17-23. Available from: http://press.endocrine.org/doi/abs/10.1210/ jc.2002-022013.

12-Schoeman JP, Rees P, Herrtage ME. Endocrine predictors of mortality in canine babesiosis caused by Babesia canis rossi. Vet Parasitol. 2007 September 148(2):75-82. Available from: http://www.sciencedirect. com/science/article/pii/S0304401707002828. doi:10.1016/j.vetpar.2007.06.010 
13-Zygner W, Gojska-Zygner O, Wedrychowickz H. Euthyroid sick syndrome in canine babesiosis caused by babesia canis. Bull Vet Inst Pulawy. 2012 December 56(4):525-527. Available from: http://www.degruyter. com/view/j/bvip.2012.56.issue-4/v10213-012-0092-3/v10213-012-0092-3.xmL . DOI: 10.2478/v10213-0120092-3

14-Saridomichelakisa MN, Xenoulis PG, Chatzisa MK, Kasabalisa D, Steinerb JM, Suchodolskib JS, Petanidesa T. Thyroid function in $36 \mathrm{dogs}$ with leishmaniosis due to Leishmania infantum before and during treatment with allopurinol with or without meglumine antimonate. Vet Parasitol. 2013 October 197(1-2):2228. Available from: http://www.sciencedirect.com/science/article. DOI: 10.1016/j.vetpar.2013.04.038

15-Dee Groot DLJ. Dangerous dogmas in medicine: the nonthyroidal illness syndrome. J Clin Endocrinol Metabol. 1999 84(1):151-164. Available from: http://press.endocrine.org/ doi/pdf/10.1210/jcem.84.1.5364

16-Van Den Berhge G. Neuroendocrine axis in critical illness. Curr Opin Endocrinol Metab. 2001 February $8(1): 47-54$.

17-AdLer SM, Wartofsky L. The nonthyroidal illness syndrome. Endocrinol Metabol Clin North Am. 2007 September 36(3):657-672. Available from: http://www.sciencedirect.com/science/article/pii/ S0889852907000400. DOI: 10.1016/j.ecl.2007.04.007.

18-Van Haasteren GA, van der Meer MJ, Hermus AR, Linkels E, Klootwijk W, Kaptein E, et al. Different effects of continuous infusion of interleukin-1 and interleukin-6 on the hypothalamic-hypophysial-thyroid axis. Endocrinol. 1994 135(4):1336-45. Available from: DOI: http://dx.doi.org/ 10.1210/endo.135.4.7925094

19-Hanisch A, Dieterich KD, Dietzmann K, Ludecke K, Buchfelder M, Fahlbusch R. Expression of member of the interleukin- 6 family of cytokines and their receptors in human pituitary and pituitary adenomas. J Clin Endocrinol Metabol. 2000 85(11):44114. Available from: http://press.endocrine.org/ doi/pdf/10.1210/ jcem.85.11.7122

20-Baur A, Bauer K, Jarry H, Kohrle J. Effects of proinflammatory cytokines on anterior pituitary 5'-deiodinase type I and type II. J Endocrinol. 2000 167(3):505-15. Available from: http://joe-endocrinology-journals-org. ez78.periodicos.capes.gov.br/content/167/3/505.full.pdf+htmL doi: 10.1677/joe.0.1670505

21-Gallego LS, Miró G, Koutinas A, Cardoso L, Pennisi MG, Ferrer L, Bourdeau P, Oliva G, Baneth G. LeishVet guidelines for the practical management of canine leishmaniosis. Parasites \& Vectors, v.4, p.86, 2011. Available from: http://www.parasitesandvectors.com/content/4/1/86 doi:10.1186/1756-3305-4-86.

22-Peterson ME, Melian C, Nichols R. Measurement of serum total thyroxine, triiodothyronine, free thyroxine, and thyrotropin concentrations for diagnosis of hypothyroidism in dogs. J Am Vet Med Assoc. 1997 211(11):1396-1402.

23-Statsoft Inc. Statistica. System for Microsoft Windows. Version 7.0. Tulsa, 2004.

24-Graves T.K.: When normal is abnormal: keys to laboratory diagnosis of hidden endocrine disease. Top Companion Anim Med 2011, 26, 45-51.

25-Bohm M, Leisewitz AL, Thompson PN, Shoeman JP. Capillary and venous Babesia canis rossi parasitaemias and their association with outcome of infection and circulatory compromise. Vet Parasitol. 2006 Oct 141(12):18-29. Available from: http://www.sciencedirect.com/science/article/pii/S0304401706002846 http://dx.doi. org/10.1016/j.vetpar.2006.05.002.

26-Van Hoek I., Daminet S.: Interactions between thyroid and kidney function in pathological conditions of these organ systems: a review. Gen Comp Endocrinol. 2009 160(3)205-215. Available from: doi:10.1016/j. ygcen.2008.12.008

27-Gommeren K, Van Hoek I, Lefebvre HP, Benchkroun G, Smets P, Daminet S. Effect of thyroxine 
supplementation on glomerular filtration rate in hypothyroid dogs. J Vet Intern Med. 2009 July/August 23(4):844-849. Available from: http://onlinelibrary.wiley.com/doi/10.1111/j.1939-1676.2009.0331.x.

28-Piechotta M, Raila J, Rick M, Beyrback M, Hoppen H.O. Serum transthyretin concentration is decreased in dogs with nonthyroidal illness. Vet Clin Pathol. 2012 March 41(1):110-113. Available from: http://onlinelibrary. wiley.com/doi/10.1111/j.1939-165X.2011.00394.x/.

29-Dias-Espineira M, Lee WM, Rijnberk A, Kooistra HS. Thyrotropin-releasing hormone-induced growth hormone secretion in dogs with primary hypothyroidism. Domest Anim Endocrinol. 2007 February 35(2):98111. Available from: http://www.sciencedirect.com/science/article/pii/S0739724007000653. DOI: 10.1016/j. domaniend.2007.02.001 